\title{
TEKNIK PENYUSUNAN LAPORAN KEUANGAN BAGI KSPPS/USPPS KOPERASI SYARIAH DI KALIMANTAN SELATAN
}

\author{
Syafril Djaelani \\ ASMI Citra Nusantara Banjarmasin \\ Email: syafril.riau@gmail.com
}

\begin{abstract}
ABSTRAK
Pengabdian kepada masyarakat dilakukan dengan memberikan pelatihan tentang teknik penyusunan laporan keuangan bagi KSPPS/USPPS koperasi di wilayah Kalimantan Selatan. Akuntansi merupakan sistem informasi yang menghasilkan laporan keuangan kepada pihak - pihak yang berkepentingan. Pengetahuan Akuntansi bermanfaat untuk mengecilkan resiko kesalahan dalam melakukan pencatatan. Berdasarkan penjelasan tersebut bahwa aktivitas koperasi yaitu menjual jasa dan aktivitas lainnya. Aktivitas koperasi tersebut juga dilakukan pada beberapa koperasi syariah di Banjarmasin. Pengetahuan akan akuntansi sangat diperlukan bagi pengerus dan anggota untuk menghindari terjadinya kecurangan dan dapat meminimalkan resiko terhadap pencatatan atas aktivitas transaksi yang terjadi pada koperasi . Kegiatan ini menggunakan pendekatan deskriptif qualitatif. Metode yang digunakan adalah cerama (Presentasi),dialog interakti dan tanya jawab. Semoga kegiatan ini akan memberikan manfaat kepada pengurus dan angggota koperasi di wilayah Kalimantan Selatan
\end{abstract}

Kata kunci : Akuntansi, laporan keuangan, kalimantan selatan, koperasi

\section{TECHNIQUE FOR PREPARATION OF FINANCIAL STATEMENTS FOR SHARIA KSPPS / USPPS COOPERATION IN KALIMANTAN SELATAN}

\begin{abstract}
Community service is carried out by providing training on financial report preparation techniques for KSPPS / USPPS cooperatives in the South Kalimantan region. Accounting is an information system that produces financial reports to interested parties. Accounting knowledge is useful to reduce the risk of errors in recording. Based on the explanation that the cooperative activity is selling services and other activities. Cooperative activities are also carried out in several Islamic cooperatives in Banjarmasin. Knowledge of accounting is very necessary for the successor and members to avoid fraud and can minimize the risk of recording the transaction activities that occur in the cooperative. This activity uses a descriptive qualitative approach. The method used is cerama (presentation), interactive dialogue and question and answer. Hopefully this activity will provide benefits to the management and members of cooperatives in the South Kalimantan region

Keyword: Accountancy, Financial Report, Sout Kalimantan, cooperatives
\end{abstract}

\section{PENDAHULUAN}

Bisnis selalu memegang peranan yang vital bagi kehidupan sosial dan ekonomi manusia sepanjang masa, sehingga kepentingan bisnis akan mempengaruhi tingkah laku bagi semua tingkatan individu, sosial, regioanl, nasional maupun internasional. Perhatian pemerintah terhadap UMKM yang sangat besar merupakan langkah strategis yang tepat bagi perekonomian bangsa. Pembentukan Kementrian Koperasi dan Usaha Kecil Menengah merupakan cerminan keseriusan dan kepedulian pemerintah terhadap UMKM.

Peran koperasi sangat penting dalam menumbuhkan dan mengembangkan potensi ekonomi rakyat serta dalam mewujudkan kehidupan demokrasi ekonomi dengan ciri-ciri; demokratis, kebersamaan, kekeluargaan dan keterbukaan (Departemen Koperasi: 1992). Oleh karena itu koperasi tidak hanya sebagai Badan Usaha yang dikelola secara kekeluargaan dan kurang profesional, namun koperasi harus dikelola dengan baik sehingga dapat menjalankan usaha dalam perekonomian rakyat (Apandi, 2014).

Perkembangan lembaga-lambaga keuangan syariah seperti bank syariah, asuransi syariah, gadai syariah, leasing syariah dan lembaga keuangan mikro syariah seperti Baitul Maal Wattamwil (BMT) syariah yang berbadan hukum koperasi cukup pesat di tanah air. Pekembangan Bank dan Lembaga Keuangan Syariah ini juga dibarengi dengan perkembangan metode pencatatan transaksinya sesuai dengan standar pencatatan (akuntansi) yang diakui secara nasional dan internasional. 
BAKTI BANUA : Jurnal Pengabdian Kepada Masyarakat

Volume 1 No. 1 Mei 2020

https://ejurnal.stimi-bjm.ac.id/index.php/BBJM/

Dari segi ilmu pengetahuan, Akuntansi adalah ilmu informasi yang mencoba mengkonversi bukti dan data menjadi informasi dengan cara melakukan pengukuran atas berbagai transaksi dan akibatnya dikelompokkan dalam akun, perkiraan atau pos keuangan seperti aktiva, utang, modal, hasil, biaya dan laba. Menariknya, Akuntansi yang selama ini dianggap hal yang sulit ternyata dapat dipahami dan dipraktekkan secara mudah.

Penerapan akuntansi merupakan langkah mudah dan memberi manfaat luar biasa bagi pelaku koperasi. Dengan akuntansi yang baik berupa laporan keuangan, maka koperasi akan memenuhi persyaratan dalam pengajuan pinjaman (financing) kepada Bank. Tujuan laporan keuangan yaitu memberikan informasi yang menyangkut posisi keuangan, kinerja dan perubahan posisi keuangan suatu perusahaan yang bermanfaat bagi sejumlah besar pemakai dalam pengambilan keputusan ekonomi (Syafril, 2019)

Permasalahan tentang pengelolaan dana merupakan faktor kunci keberhasilan atupun kegagalan koperasi, meskipun banyak faktor-faktor lain lagi yang mempengaruhinya. Oleh karena itu, metode praktis dan yang paling baik dalam pengelolaan dana adalah dengan menerapkan akuntansi secara baik. Dengan demikian, akuntansi menjadikan koperasi dapat memperoleh informasi yang penting dalam menjelankan bisnisnya.

\section{KAJIAN LITERATUR}

1. Pengertian Koperasi

Menurut Undang-Undang Perkoperasian Republik Indonesia Nomer 17 tahun 2012, yang dimaksud koperasi adalah badan hukum yang didirikan oleh orang perseorangan atau badan hukum koperasi, dengan pemisahan kekayaan para anggotanya sebagai modal untuk menjalankan usaha, yang memenuhi aspirasi dan kebutuhan bersama dibidang ekonomi, social dan budaya sesuai dengan nilai dan prinsip koperasi, yaitu :

a) Keanggotaan koperasi bersifat sukarela dan terbuka

b) Pengawasan oleh anggota diselenggarkan secara demokratis,

c) Anggota berpartisipasi aktif dalam kegiatan ekonomi koperasi

d) Koperasi merupakan badan usaha swadaya yang otonom dan independen

e) Koperasi menyelenggarakan pendidikan dan pelatihan bagi anggota, pengawas, pengurus dan karyawannya serta memberikan informasi kepada masyarakat tentang jatidiri, kegiatan dan kemanfaatan koperasi

f) Koperasi melayani anggotanya secara prima dan memperkuat gerakan koperasi dengan bekerjasama melalui jaringan kegiatan pada tingkat local, nasional, regional dan internasional.

g) Koperasi bekerja untuk pembangunanberkelanjutan bagi lingkungan dan masyarakatnya melalui kebijakan yang disepakati oleh anggota

2. Pengertian Akuntansi

Akuntansi sering disebut sebagai "The Languages of Bussiness". Secara umum kata akuntansi berasal dari bahasa Inggris "Account" yang berarti perkiraan. Secara luas "Akuntansi adalah suatu seni untuk melakukan pencatatan, pengelompokkan,pengikhtisaran dan pelaporan sertapenganalisaan terhadap transaksi-transaksi ekonomi perusahaan guna pengambilan suatu keputusan' (Faud, 2005). Sedangkan menurut (Nurhayati, 2008), Akuntansi adalah identifikasi transaksi yang kemudian diikuti dengan kegiatan pencatatan, penggelompokkan, serta pengikhtisaran transaksi tersebut sehingga menghasilkan laporan keuangan yang dapat digunakan untuk pengambilan keputusan. Sedangkan pengertian syariah adalah aturan yang ditetapkan oleh Allah swt untuk dipatuhi oleh manusia dalam menjalani aktivitasnya.

3. Laporan Keuangan

Menurut Sawir (2005:2), laporan keuangan adalah hasil akhir proses akuntansi. Sedangkan Simagungsong (1995:1), mengatakan laporan keuangan ialah laporan secara sistematis hasil/keadaan keuangan suatu perusahaan dan merupakan sumber informasi keuangan kepada pihak yang membutuhkan baik internal maupun pihak eksternal. Sedangkan Nuh (2005:173), mengatakan laporan keuangan (financial statement) adalah laporan yang dibuat pada akhir periode akuntansi yang terdiri dari laporan perhitungan laba rugi (income statement), neraca (balance sheet), laporan perubahan modal (capital statement) serta laporan tambahan seperti laporan arus kas (cash flow). Laporan keuangan dibuat secara sistematis pada akhir periode akuntansi yang dapat dijadikan sumber informasi 
BAKTI BANUA : Jurnal Pengabdian Kepada Masyarakat

Volume 1 No. 1 Mei 2020

https://ejurnal.stimi-bjm.ac.id/index.php/BBJM/

keuangan suatu perusahaan bagi pihak intern maupun ekstern. Laporan keuangan disusun sedemikian rupa sesuai dengan PSAK sehingga dapat dibaca dengan jelas untuk dianalisa dan dijadikan pedoman dalam proses pengambilan keputusan.

\section{METODE KEGIATAN}

Kegiatan pengabdian kepada masyarakat ini menggunakan metode ceramah (presentation), dialog interaktif dan tanya jawab secara langsung yang dilakukan peserta pada saat prensentasi dilakukan. Peserta dapat bertanya kapan saja diinginkan tanpa harus melalui moderator. Metode ini dilakukan agar peserta memahami setiap langkah demi langkah dalam menyusun laporan keuangan koperasi syariah.

\section{HASIL DAN PEMBAHASAN}

Kegiatan pengabdian masyarakat ini dilaksanakan di Hotel Rodhita Banjarmasin, Jalan Pangeran Antasari No.41, Kelayan Luar, Banjarmasin, Kota Banjarmasin, Kalimantan Selatan 70249 pada hari Kamis - Jum'at, tanggal 3-4 Oktober 2019yang dihadiri oleh peserta pengurus dan pengawas koperasi syariah di wilayah Kalimantan Selatan. Pada pelaksanaan selama 2 (dua) hari mulai pukul 09.00 - 17.00 wita diawasi secara langsung oleh pegawai Dinas Koperasi dan UKM Povinsi Kalimantan Selatan. Kegiatan kali ini menghadirkan beberapa narsumber ahli dibidangnya yakni dari Dinas Koperasi dan UKM Provinsi, PINBUK Kalsel, dan Akademisi. Materi pelatihan yang saya berikan berjudul "TeknikPenyusunan Laporan Keuangan Bagi KSPPS/USPPS Koperasi Syariah" merupakan teknik untuk menyusun laporan keuangan secara singkat dan jelas bagi para peserta yang terdiri dari pengurus koperasi-koperasi syariah ataupun Baitul Mal Wattamwil (BMT) di Kalimantan Selatan.

Materi yang disampaikan pada pelatihan ini terdiri dari beberapa bagian yang menjelaskan tahapan demi tahapan dalam menyusun laporan keuangan koperasi syariah yang antara lain berikut:

1. Pengertian dan aktivitas koperasi

2. Pengertian, siklus dan tujuan akuntansi koperasi syariah

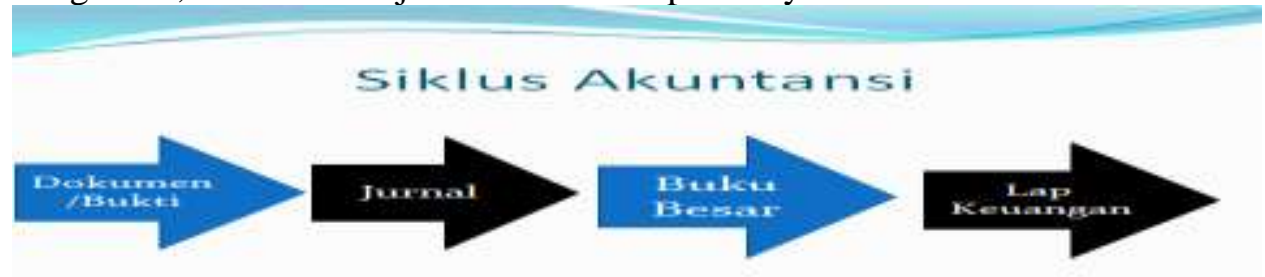

GAMBAR 1. Siklus Akuntansi

3. Tujuan dan komponen laporan keuangan

Tujuan dari laporan keuangan koperasi adalah untuk pengambilan putusan investasi dan pembiayaan. Menyediakan informasi yang bermanfaat bagi pihak-pihak yg berkepentingan dalam pengambilan keputusan yang rasional.

Pihak-pihak berkepentingan, adalah:

a. Shahibul maal/pemilik dana

b. Kreditur / bank

c. Pembayar zakat, infaq dan shadaqah

d. Anggota koperasi

e. Otoritas pengawasan / pemerintah

f. Masyarakat

Adapun komponen laporan keuangan terdiri dari:

a. Neraca, memberikan informasi posisi keuangan.

b. Laporan perhitungan hasil usaha, memberikan informasi tentang penghasilan dan beban

c. Laporan arus kas, memberikan informasi tentang perubahan historis atas kas dan setara kas koperasi

d. Catatan atas laporan keuangan, penjelasan tambahan informasi tentang laporan keuangan 
BAKTI BANUA : Jurnal Pengabdian Kepada Masyarakat

4. Ketentuan umum laporan keuangan membahas tentang:
a. Tujuan laporan keuangan
b. Tanggungjawap atas pelaporan keuangan di manajemenperusahaan
c. Bahasa laporan keuangan
d. Mata uang pelaporan
e. Kebijakan akuntansi
f. Penyajian

5. Karakteristik kualitatif usaha koperasi simpan pinjam yakni:
a. Dapat dipahami, kemudahan untuk dipahami oleh pengguna
b. Relevan, relevan dengan kebutuhan pengguna untuk pengambilan keputusan
c. Keandalan, bebas dari kesalahan material dan bias yang dapat mempengaruhi keputusan
d. Dapat dibandingkan, dapat membandingkan laporan keuangan koperasi antar periode

6. Prinsip akuntansi dan pelaporan keuangan merupakan:

a. Basis akuntansi, laporan keuangan disusun atas dasar akrual

b. Laporan keuangan harus disajikan secara wajar

* Aset disajikan menurut urutan likuiditas, sedangkan kewajiban menurut jatuh temponya

* Laporan arus kas dikelompokkan secara single step

* Catatan atas lapkeu disajikan secara sistematis sesuai komponen utamanya

* Dalam catatan laporan keuangan mengunakan jumlah nominal atau persentase

c. Pengungkapan lengkap, informasi dalam laporan keuangan harus lengkap dalam batasan materialits dan biaya

d. Substansi mengungguli bentuk, transaksi dicatat dan disajikan sesuai substansi dan realitas ekonomi

e. Netralitas, informasi diarahkan pada kebutuhan umum pemakai bukan untuk pihak tertentu

f. Pertimbangan sehat,mengandung unsur kehati-hatian pada saat melakukan prakiraan

g. Tepat waktu, lapkeu harus disajikan tepat waktu sehingga bermanfaat

h. Konsisten, laporan keuangan antar periode harus konsisten

7. Perkiraan dan akun-akun dalam akunansi koperasi

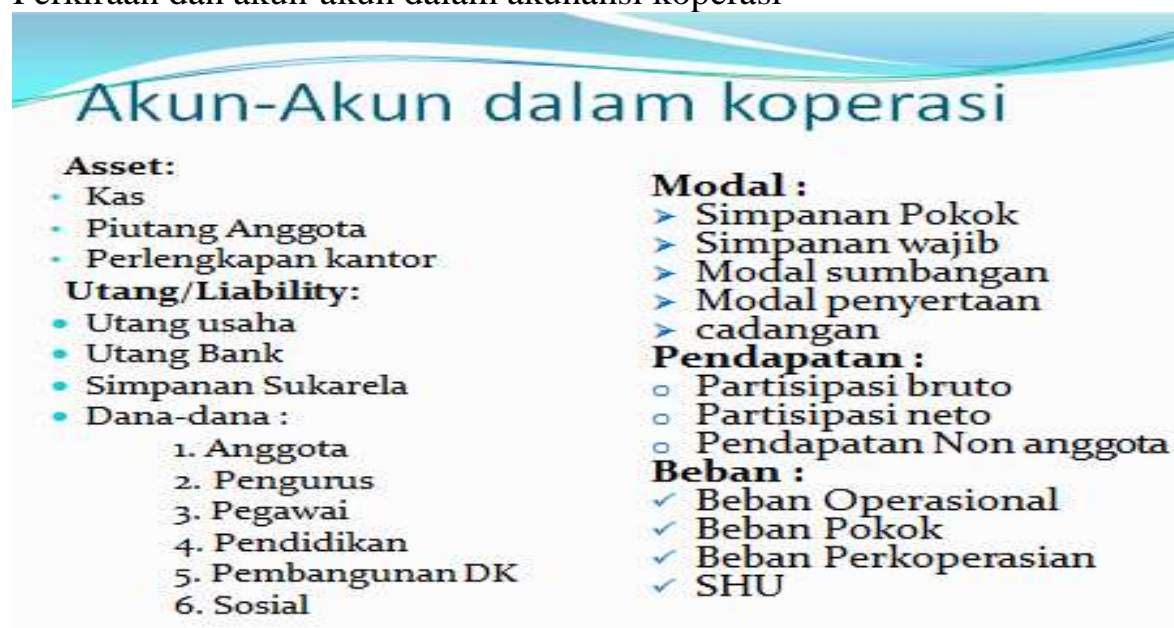

GAMBAR 2. Akun Koperasi

Akun akuntansi adalah suatu media untuk mencatat transaksi-transaksi keuangan yang dimiliki koperasi secara spesifik seperti aset, utang, modal, pendapatan dan beban (Bati, 2019).

8. Contoh-cotoh transaksi dan jurnal transaksi

9. Laporan keuangan koperasi 
BAKTI BANUA : Jurnal Pengabdian Kepada Masyarakat

https://ejurnal.stimi-bjm.ac.id/index.php/BBJM/
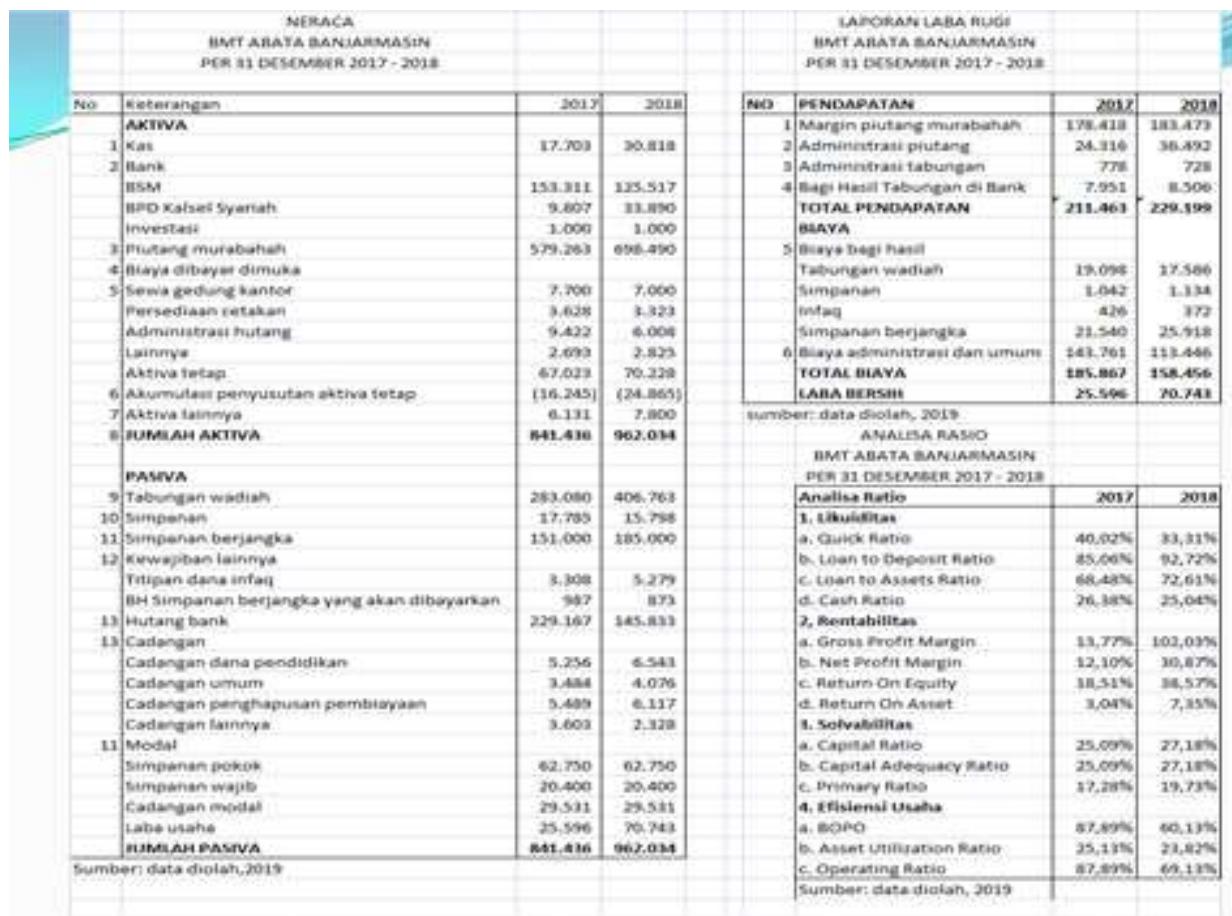

GAMBAR 3. Laporan Keuangan

Dari hasil proses pencatatan transaksi keuangan koperasi secara benar akan menghasilkan laporan keuangan yang akan dipergunakan oleh pihak-pihak yang membutuhkan seperti investor, perbankan, masyarakat luas dalam proses pengambilan keuputusan keuangan.

10. Ekuitas / modal koperasi terdiri dari:
a. Modal Anggota
b. Modal Sumbangan
c. Modal Penyertaan
d. Modal Penyertaaan Pertisipasi Anggota
e. SHU Periode Berjalan
f. Cadangan

11. Metode dan contoh pembagian SHU

\section{MetodePembagian SHU:}

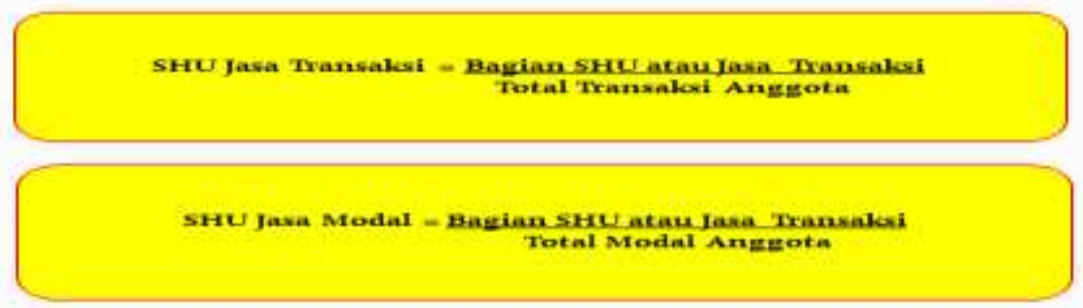

GAMBAR.3. Metode Pembagian SHU

SHU yang diperoleh masing-masing anggota berdasarkan kontribusi anggota terhada perolehan SHU tersebut. Semakin besar jumlah simpanan dan belanja anggota maka akan semakin besar pula anggota memperoleh bagian dari Sisa Hasil (SHU) dari koperasi.

12. Gambar-gambar suasana pelatihan 


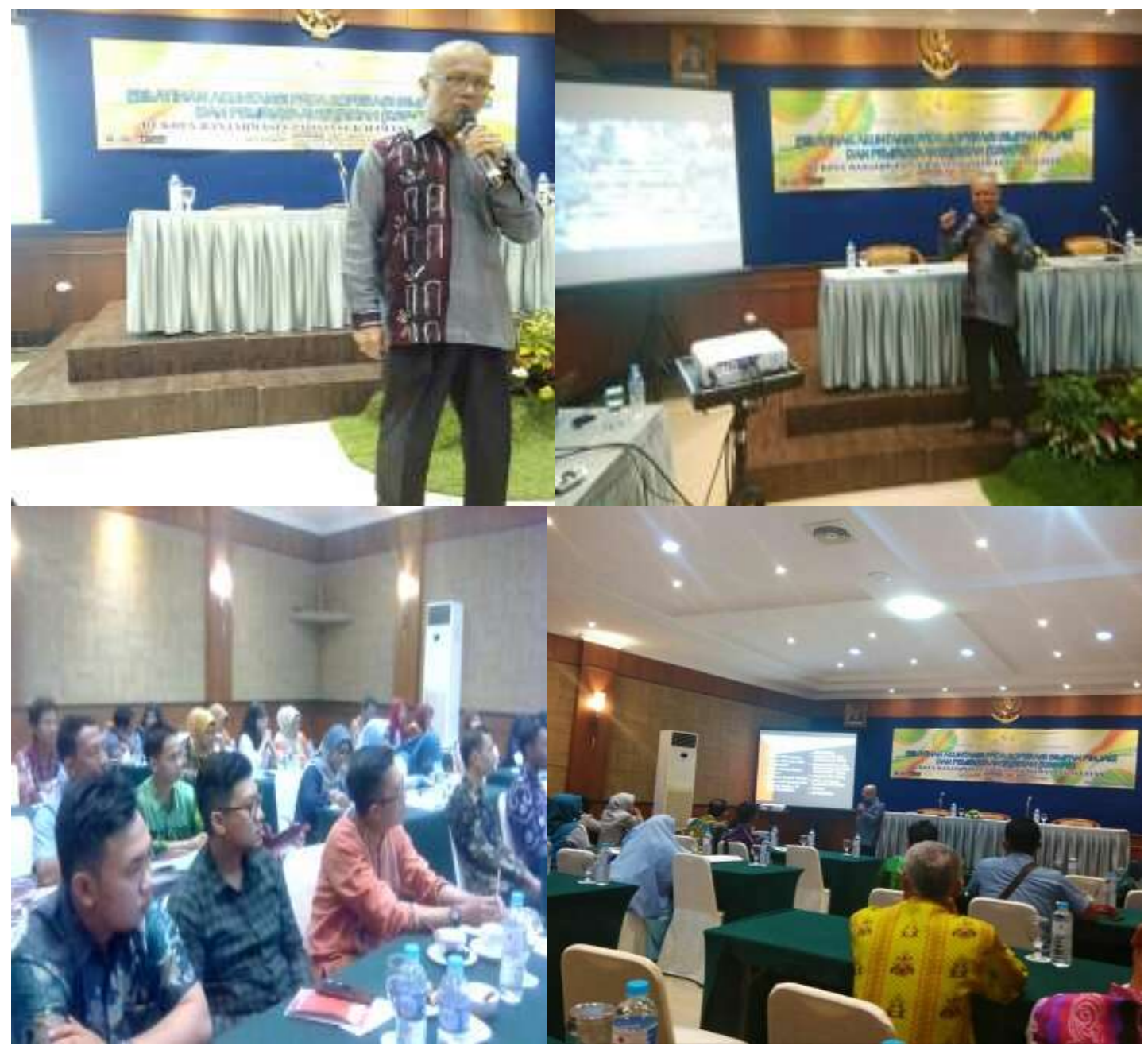

PENUTUP

Pelatihan yang diberikan kepada seluruh peserta yang hadir yang terdiri dari pengurus dan pelaksana dari koperasi diharapkan dapat menambah pengetahuan dan dapat diterapkan di masingmasing koperasi di unit kerjanya masing-masing. Pentingnya koperasi menerapkan akuntansi sesuai ketentuan diharapkan akan menambah kepercayaan masyarakat untuk berinvestasi dan bertransaksi dengan koperasi yang secara langsung akan berdampat terhadap kemajuan dunia usaha terutama usaha mikro kecil yang menjadi binaan dari koperasi selama ini.

Pelatihan Teknik Penyusunan Laporan Keuangan KSPPS/USPPS Koperasi yang diselenggarakan oleh Dinas Koperasi Provinsi Kalimantan Selatan berkerja sama dengan Pusat Inkubasi Bisnis Usaha Kecil (PINBUK) dan akademisi menambah pengetahuan dan keterampilan peserta dalam bidang akuntansi terutama dalam penyusunan laporan keuangan koperasi syariah.

\section{DAFTAR PUSTAKA}

Apandi, Pandi, "Analisis Kinerja Keuangan Untuk Mengukur Kesehatan Keuangan Koperasi KSU BMT Arafah Kecamatan Bancak Kabupaten Semarang”, Jurnal Among Makarti, Vol.7 No,13, Juli 2014

Bati, Hilmiatus Sahla, Dian Ayu Andriani, "Pelatihan Akuntansi Pengurus dan Anggota KSU Pemuda Kisaran” Jurnal Anandara Pengabdian Kepada Masyarakat, Volume 1 No.1, 2019

Faud, Ramly Muhammad, M.Rustan D.M, “Akuntansi Perbankan”, Graha Ilmu, Yogyakarta, 2005 Gamal, Merza, "Aktivitas Ekonomi Syariah" UNRI Press, Pekanbaru, 2004

Nuh, Muhammad, “Accounting Principless”, Edisi 1, Penerbit Fajar, Jakarta 
BAKTI BANUA : Jurnal Pengabdian Kepada Masyarakat

Volume 1 No. 1 Mei 2020

https://ejurnal.stimi-bjm.ac.id/index.php/BBJM/

Nurhayati, Sri, Wasilah. "Akuntansi Syariah Di Indonesia”, Salemba Empat, Jakarta, 2008

Sawir, Agnes, "Analisa Kinerja Keuangan dan Perencanaan Keuangan Perusahaan”, Gramedia Pustaka utama, Jakarta, 2005

Simagungsong, MP, 1995,Pelajaran Akuntansi Dasar Dua, Edisi 10, Karya Utama, Jakarta

Warsono, Sony, Endra Murti Sagoro, M. Arsyadi Ridha, Ari Darmawan, “Akuntansi UMKM”

Asghard Chapter, Yogyakarta, 2010

\section{Profil Penulis}

Syafril, S.E,.M.M, Keilmuan Manajemen, ASMI Citra Nusantara Banjarmasin, Jalan Soetoyo S No.169 Banjarmasin 70114

Email: syafril.riau@gmail.com 